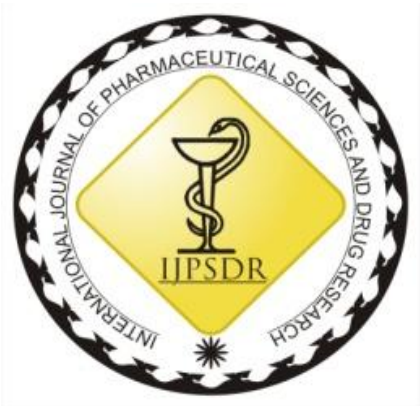

\author{
RESEARCH ARTICLE
}

ISSN: 0975-248X

CODEN (USA): IJPSPP

$(\mathrm{cc})$ EY-NC-SA

\title{
Analysis of Metformin on Endogenous Antioxidants and Oxidative Stress in Mice Brain Tissue of Alloxan-Induced Diabetes
}

\author{
Harsha Kashyap, Sarika Gupta* \\ Department of Bioscience and Biotechnology, Banasthali University, P.O. Banasthali Vidyapith-304 022, Tonk, \\ Rajasthan, India
}

Copyright (C) 2019 Harsha Kashyap et al. This is an open access article distributed under the terms of the Creative Commons AttributionNonCommercial-ShareAlike 4.0 International License which allows others to remix, tweak, and build upon the work non-commercially, as long as the author is credited and the new creations are licensed under the identical terms.

\begin{abstract}
Diabetes has become a serious threat to mankind, as it is found in all parts of the world. Alloxan induced diabetic mice were treated by Metformin to study the impact of oxidative stress and endogenous antioxidants. Due to the establishment of diabetes, the oxidative stress indicators were found to be positively correlated with the elevation in the levels of endogenous antioxidants. Whereas, in Metformin-treated diabetic mice, the data revealed the correction of diabetes by lowering of blood glucose level along with body weight. But the levels of endogenous antioxidants were not recorded to increase except GST. It shows that under in vivo system level of oxidative stress increases due to the Metformin. The data revealed that Metformin treatment of mice, however, manage the glucose level but not effective in controlling oxidative stress.
\end{abstract}

Keywords: Alloxan, Oxidative stress, Endogenous antioxidants, blood glucose level, in vivo system, Metformin.

DOI: 10.25004/IJPSDR.2019.110519

Int. J. Pharm. Sci. Drug Res. 2019; 11(5): 272-277

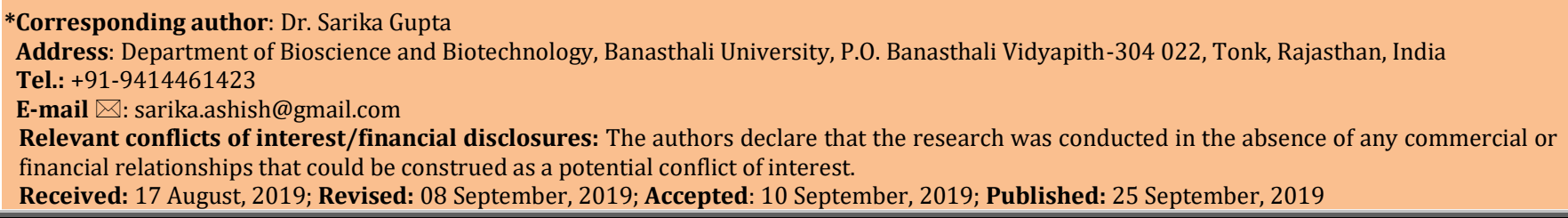

\section{INTRODUCTION}

Globally diabetes has become a grave issue to humankind. [1] As a data of 2015, in India 69.2 million people i.e., $8.7 \%$ were suffering from diabetes. Diabetic mortality and morbidity have increased worldwide and it is expected that by 2030 diabetes would be at the top to cause death due to non-communicable diseases. [2] Diabetes is classified in three types, type I, type II and gestational DM. Type I diabetes is known as the immune-mediated damage of beta cells that secrete insulin. [3] Presence of islet cells autoantibodies directed against the autoantigens insulin GAD65 and the islet tyrosine phosphatase IA-2 is the main cause of $\beta$-cell damage. Type I diabetes is a T-cell mediated disease associated with lack of immunological tolerance to selfantigens. ${ }^{[4]}$ There is a lack of insulin formation due to the pancreatic cellular destruction. [5] Type II diabetes is a diabetes mellitus, which is insulin-independent ${ }^{[6]}$ and defined as the progressive decline in the function of the $\beta$ cell as well as chronic insulin resistance. ${ }^{77}$ The persistent problems of diabetes contain increased development of cardiovascular disease, renal disease, weak vision and limbic problems. ${ }^{[8]}$ In the diabetic patient insulin is an anabolic hormone because in 
diabetes type 1 one has the deficiency of insulin whereas in diabetes type 2 one has to access in insulin level. [9] Gestational DM is defined as glucose intolerance during the initial stage of pregnancy. [10] Hypertension, blindness, stroke, coronary-artery disease and kidney disease as well as peripheral neuropathy are common complications of diabetes. [11]

In several studies, under in vivo conditions (experimental mice) alloxan is used for inducing diabetes by disturbing $\beta$ cells of the pancreas. [12-30] Metformin is one of the commercially available efficient, inexpensive and easily available drugs for the treatment of diabetes. It is clinically most common drug for diabetes but shows some side effects as complications with eyes, kidneys, heart and vasculature, peripheral nerves. The primary action of metformin is to improve insulin sensitivity of the liver as a result of which basal endogenous glucose production decreases. [31] Metformin is a chemical which is extracted from plant Galega officinalis. In 1957, Jean Sterne introduced it as a "Glucophage". [32] Earlier report suggests that metformin alters oxidative responses in brain. [33] Primary action of metformin is to improve insulin sensitivity of the liver as a result of which basal endogenous glucose production decreases by activating Adenosine Mono Phosphate activated Protein Kinase (AMPA-PK) ${ }^{[31]}$ (Fig. 1).
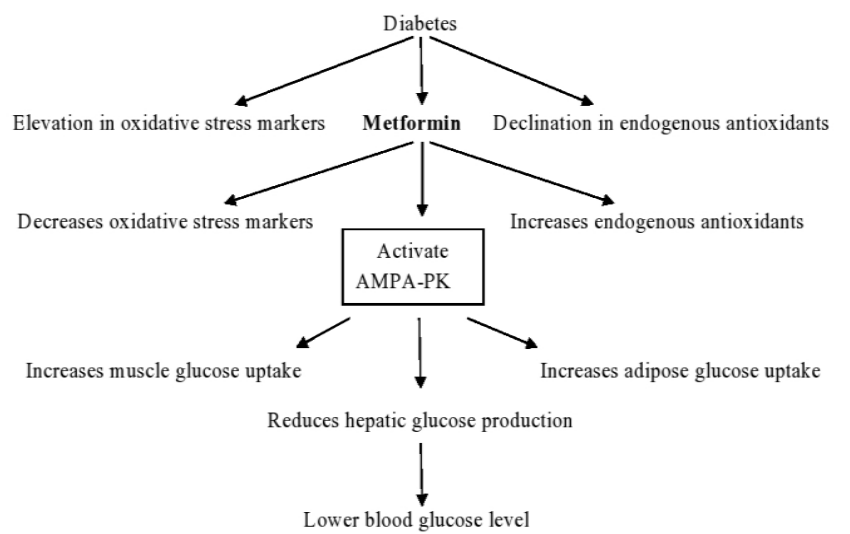

Fig. 1: Cascade of events associated with Metformin action in diabetic response.

The genetic factor is one of the predisposing factors of causing diabetes. Its treatment and complications have a high healthcare expenditure, as it is a multifactorial disease. Age, obesity, genetic predisposition and lifestyle are the major cause of diabetes onset. Hypertension, stroke, coronary-artery disease, blindness, kidney disease as well as peripheral neuropathy are the complications of diabetes. [34] Antioxidants scavenge free radicals to prevent cellular damage. It can reduce the oxidative stress. Oxidative stress is also be defined as imbalance and cytopathological effects of free radicals generation and their cell ability. [35-36] Glucose oxidation can lead to the generation of free radicals, which may cause cell death. Establishment of diabetes can cause damage to membrane lipids, nucleic acids and cellular proteins. [37] The present study aims to find the behavior of Metformin, most commonly used drug for diabetes by measuring the activities with respect to endogenous antioxidants and oxidative stress also amount of total protein in diabetic as well as Metformin treated diabetic mice.

\section{MATERIALS AND METHODS}

\section{Experimental Animals}

Healthy male mice (Mus musculus) of age six weeks were purchased from C. C. S. Haryana Agriculture University and kept in a polypropylene cages bedded by a thick layer of husk, in animal house. They were provided with feed and water ad libitum. Committee for the Purpose of Control and Supervision of Experiments on Animals (CPCSEA) has approved the mice for study (BV/3523/2017-18).

For the study, mice were categorized into three groups $(n=7)$ as Group I is a control group which was treated with normal saline. Single dose of alloxan (160 mg per $\mathrm{kg}$ body weight) was administered to the mice of group II and III that induced diabetes in mice diabetes were validated after 24 hours of administration of alloxan (i.p.). Diabetic mice of group III received oral dose of Metformin $(180 \mathrm{mg} / \mathrm{kg}$ ) for 21 days continuously. Tip of mice tail was cut with scissor and pressed to get blood on glucometer strip. [38-40]

\section{Biochemical Parameters}

For study mice were isolated in three different groups: Control (group I), Diabetic (group II) and metformin treated diabetic mice (group III) whole brains of mice were used to determine the level of various antioxidants. On the completion of 21 days the brains were isolated to determine the activities of endogenic antioxidants and oxidative stress of the brain. Total protein amount in the brain of all the group of mice was also calculated.

\section{Protein estimation}

Amount of protein in mice brain was calculated by Lowry method. [41] Concentration of total protein in mice brain was measured by taking a sample volume followed by adding $5 \mathrm{ml}$ of alkaline copper sulphate solution and after 10 minutes of incubation $5 \mathrm{ml}$ of folin-reagent was added; kept for 30 minutes of dark incubation and absorbance read at $660 \mathrm{~nm}$ with BSA 0.1 to 1.0 as standard.

Endogenous antioxidants of brain

Reduced glutathione (GSH): It was calculated by Ellman et al ${ }^{[42]}$ method. After reacting with DTNB GSH forms a yellow colored 5-thio-2-nitrobenzoic acid, calculated at $412 \mathrm{~nm}$ on spectrophotometer. Cuvette contained a reaction volume of $25 \mu$ l sample added with $2.5 \mathrm{ml}$ phosphate buffer, $800 \mu 1$ EDTA and $100 \mu 1$ DTNB.

Sodium dismutase (SOD): SOD activity was measured by the method of Dhindsa et al. [43] It is estimated by the inhibition of NBT reduction. Reaction mixture was made by adding $1.5 \mathrm{ml}$ phosphate buffer, $100 \mu \mathrm{l}$ NBT, $50 \mu \mathrm{l}$ of sample, $100 \mu \mathrm{l}$ of sodium carbonate, $200 \mu \mathrm{l}$ 
methionine, $100 \mu \mathrm{l}$ EDTA, $1 \mathrm{ml}$ distilled water and $100 \mu \mathrm{l}$ riboflavin. After the completion of 60 minutes incubation spectrophotometric reading was measured at $560 \mathrm{~nm}$ against blank.

Catalase (CAT): Catalase was measured by [44] method. After decomposition of $\mathrm{H}_{2} \mathrm{O}_{2}$ it releases water and oxygen. Its total reaction volume contained $1.975 \mathrm{ml}$ phosphate buffer, $1 \mathrm{ml} \mathrm{H}_{2} \mathrm{O}_{2}$ and $25 \mu \mathrm{l}$ samples. Spectrophotometric analysis was done taken at $240 \mathrm{~nm}$. Glutathione peroxidase (Gpx): Activity of $\mathrm{GpX}$ was calculated by Mohandas et al, $1984{ }^{[45]}$ method. It was determined by the coupled enzyme assay. For its assay $25 \mu \mathrm{l}$ sample, $1.44 \mathrm{ml}$ phosphate buffer, $0.1 \mathrm{ml}$ EDTA, $0.1 \mathrm{ml}$ sodium azide, $0.05 \mathrm{ml}$ glutathione reductase, 0.1 $\mathrm{ml} \mathrm{GSH}, 0.1 \mathrm{ml} \mathrm{NADPH}$ and $0.01 \mathrm{ml} \mathrm{H}_{2} \mathrm{O}_{2}$ was mixed properly and reaction by mixture was scanned at 340 nm.

Glutathione-S-Transference (GST): Level of GST was calculated by Habig et al, $1974{ }^{\text {[46] }}$ method. GST detoxify xenobiotics. Reaction mixture contained $0.1 \mathrm{ml}$ sample, $1.675 \mathrm{ml}$ phosphate buffer, $0.2 \mathrm{ml}$ reduced glutathione and $0.025 \mathrm{ml}$ CDNB and sample vial was observed at $340 \mathrm{~nm}$.

\section{Oxidative stress markers}

Thio Barbutyric Acid Reactive Substances (TBARS): Malondialdehyde (MDA) amount was calculated by TBARS which is a reactive compound formed due to the peroxidation of lipid by Ohkawa et al 1979 [47] method. It gives pink color when react with TBA under oxidative stress. In a test tube $25 \mu \mathrm{l}$ sample, $0.2 \mathrm{ml} \mathrm{KCl}$, $0.2 \mathrm{ml}$ SDS. $1.5 \mathrm{ml}$ acetic acid and $1.5 \mathrm{ml}$ TBA was pippeted. Distilled wáter was used for volumen make up to $4.0 \mathrm{ml}$. It was kept on water bath at $95^{\circ} \mathrm{C}$ for 1 hour and cooled at room temperature. In each tube $5 \mathrm{ml}$ solution of butanol: pyridine was pipetted and mixed well followed by centrifugation for 10 minutes at 3000 rpm. After discarding the uppermost layer, absorbance was noted at $532 \mathrm{~nm}$.

Protein Carbonyl Content (PCC): It is a technique to detect and quantify oxidative modification of protein via carbonyl groups by Levine et al 1990 [48] method. In a tubes $25 \mu \mathrm{l}$ sample, $1 \mathrm{ml}$ phosphate buffer and $100 \mu \mathrm{l}$ of TCA was mixed well and incubated for 15 minutes. Then it was centrifuged for 10 minutes at $8000 \mathrm{rpm}$. Discard supernatant and pellet was suspended in to $500 \mu 1 \mathrm{DNPH}$. After the incubation of 1 hour $500 \mu \mathrm{l}$ TCA was mixed and centrifuged at $5000 \mathrm{rpm}$ for 10 minutes. $1.5 \mathrm{ml}$ ethyl acetate: ethanol (1:1) was added to precipitate and centrifuged at $8000 \mathrm{rpm}$ for 10 minutes to wash excess of DPNH. Washing of DNPH was done 3 times. Spectrophotometric reading was taken at 370 $\mathrm{nm}$ after dissolving e final pellet in $2 \mathrm{ml}$ of guanidine hydrochloride.

\section{Statistical analysis}

To detect the reproducibility of results all biochemical test were performed in sets of three. The results are expressed as means $\pm S D, n=7$ per group from an independent experiment. A one way ANOVA between the means of 2 groups were evaluated and $p<0.05$ were measured as the analysis of significant data statistically. All graphs are plotted in sigma plot 12.0.

\section{RESULTS}

In current investigation, single dose of alloxan (160 $\mathrm{mg} / \mathrm{kg}$ ) induced diabetes in mice. [49] Glucose level in mice brain was analysed by GlucoOne glucometer. Tail was littile pressed to get the drop of blood at the glucometer strip. Diabetic mice had blood glucose level not less than $200 \mathrm{mg} / \mathrm{dl}$. [50] Body weight of all the groups of mice was noted every day. The Body weight of diabetic mice was found maximum $(29.333 \pm 0.816 \mathrm{~g})$ then in group III $(26.166 \pm 0.408 \mathrm{~g})$ and minimum in group I $(25 \pm 0 \mathrm{~g})$. Simultaneously after glucometer testing of mice blood, it was found that glucose level in diabetic mice group II was maximum (384.142 \pm 15.093 $\mathrm{mg} / \mathrm{dl})$ followed by control group I (145.166 \pm 7.44 $\mathrm{mg} / \mathrm{dl}$ ) and recorded minimum in Metformin treated diabetic mice group III (133 $\pm 16.012 \mathrm{mg} / \mathrm{dl})$ (Fig. 2).

Level of protein in brain was measured highest in diabetic mice $(0.7864 \pm 0.045 \mathrm{mg} / \mathrm{ml})$ followed by group I $(0.5282 \pm 0.013 \mathrm{mg} / \mathrm{ml})$ and group III $(0.5665 \pm$ $0.041 \mathrm{mg} / \mathrm{ml})(p<0.05)$ (Fig. 3). Similar finding were reported by Maritum et al 2003, indicating the elevation of protein content due to cellular damage in diabetes. [37]

Another part of the study involved the assessment of endogenous antioxidants parameters as SOD, GSH, CAT, GpX as well as GST, which are used as the markers of the toxicity to determine the level of diabetic neuropathies. [42-44] The level of SOD in brain was measured highest in Diabetic mice $(0.087 \pm 0.004 \mu \mathrm{g} / \mathrm{mg}$ of protein) followed by group I $(0.065 \pm 0.007 \mu \mathrm{g} / \mathrm{mg}$ of protein) and group III $(0.06 \pm 0.004 \mu \mathrm{g} / \mathrm{mg}$ of protein $)$ $(p<0.05)$. GSH level was recorded to be maximum in diabetic mice $(2.1413 \pm 0.05 \mu \mathrm{M} / \mathrm{min} / \mathrm{mg}$ of protein) and it differed significantly from group I $(1.178 \pm 0.13 \mu$ $\mathrm{M} / \mathrm{min} / \mathrm{mg}$ of protein) and group III (1.403 \pm $0.106 \mu \mathrm{M} / \mathrm{min} / \mathrm{mg}$ of protein) $(p<0.05)$. CAT level was measured notably highest in diabetic group (46.849 \pm $1.7530 \mu \mathrm{M}$ of $\mathrm{H}_{2} \mathrm{O}_{2}$ consumed/mg of protein) of mice in compared to group I $\left(34.250 \pm 3.549 \mu \mathrm{M}\right.$ of $\mathrm{H}_{2} \mathrm{O}_{2}$ consumed/mg of protein) and Group III (8.904 \pm $0.189 \mu \mathrm{M}$ of $\mathrm{H}_{2} \mathrm{O}_{2}$ consumed/mg of protein) $(p<0.05)$. Similar reports were suggested for CAT. Catalase activity increases in the brain of alloxan induce diabetic mice. [36]

Level of Gpx was also noted highest in group II (0.737 \pm $0.05 \mu \mathrm{M}$ of NADPH oxidized/mg of protein) whereas in group I $(0.5856 \pm 0.03 \mu \mathrm{M}$ of NADPH oxidized $/ \mathrm{mg}$ of protein) and group III $(0.577 \pm 0.01 \mu \mathrm{M}$ of $\mathrm{NADPH}$ oxidized/mg of protein) $(p<0.05)$ it was found very close to each other. But in GST diabetic mice shows minimum activity $(1099 \pm 20.7$ nMCDND conjugate formed $/ \mathrm{min} / \mathrm{mg}$ of protein) in compared to group I (1204 \pm 12.4 nMCDND conjugate formed $/ \mathrm{min} / \mathrm{mg}$ of protein) and group III $(1269 \pm 32.29 \mathrm{nMCDND}(p<0.05)$ conjugate formed $/ \mathrm{min} / \mathrm{mg}$ of protein) (Fig. 4). 


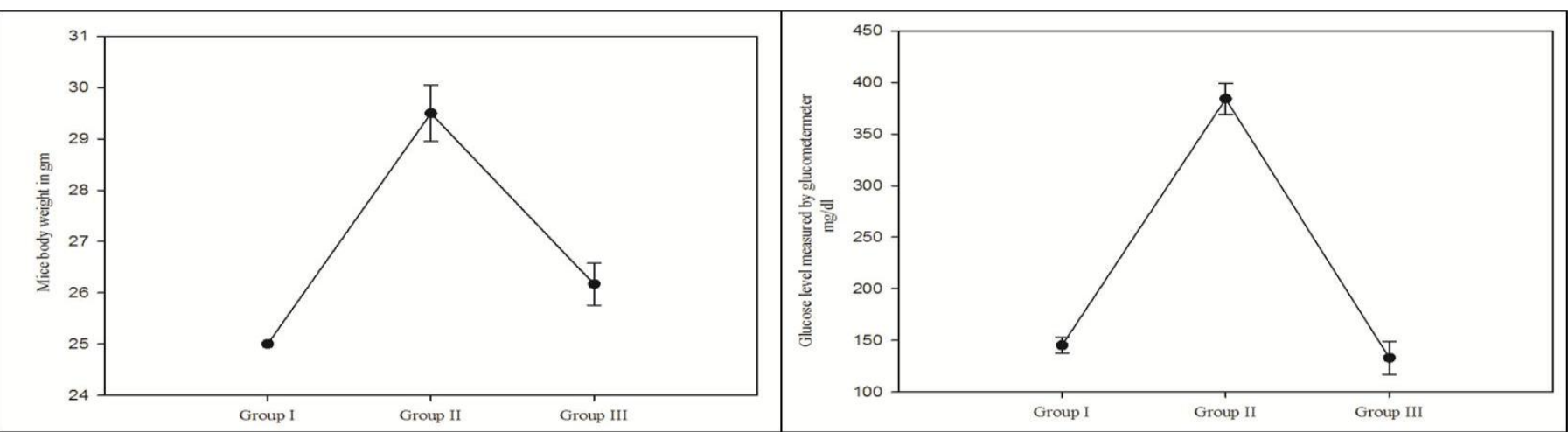

Fig. 2: Body weight and Blood glucose levels of differently treated mice. Group I: Control, Group II: Alloxan treated, Group III: Alloxan + Metformin treated mice.

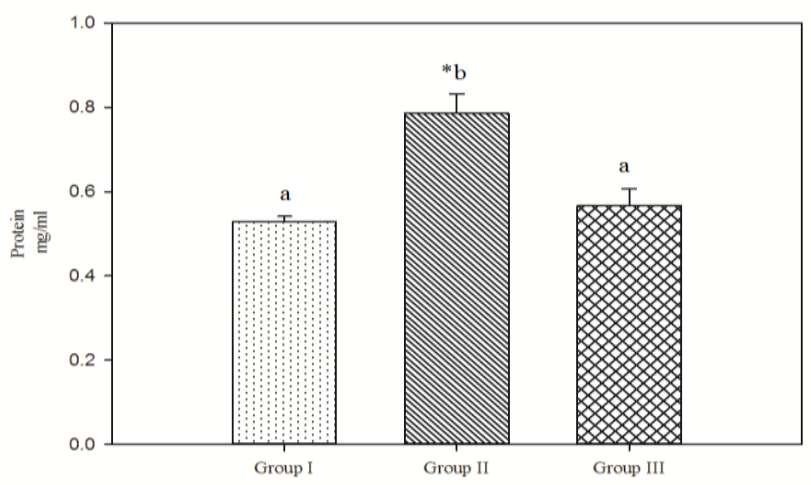

Fig. 3: Total protein concentrations in the brains of differently treated mice. Group I: Control, Group II: Alloxan treated, Group III: Alloxan + Metformin treated mice.

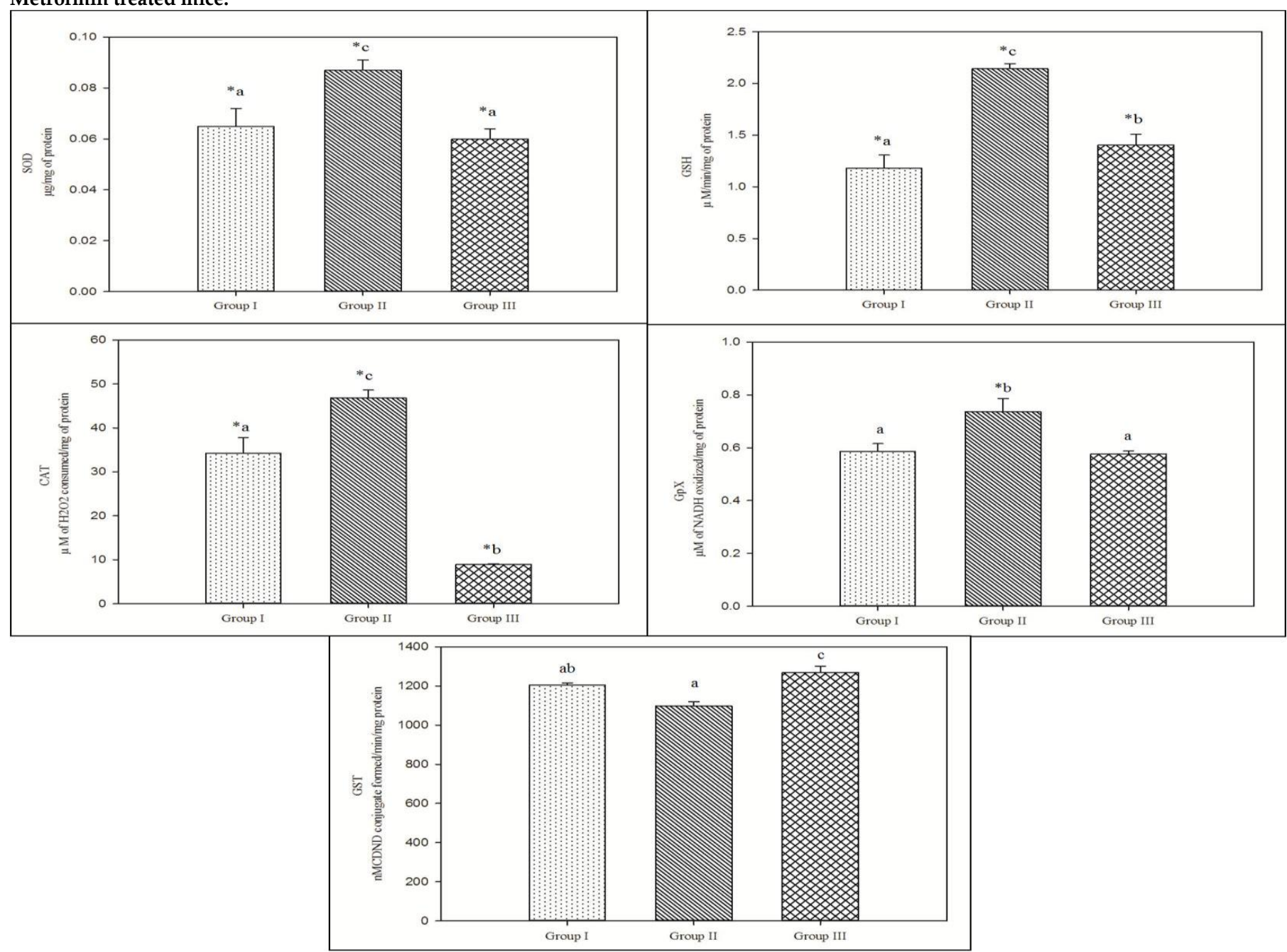

Fig. 4: Levels of Sodium Dismutase (SOD), Reduced Glutathione (GSH), Catalase (CAT), Glutathione peroxidase (Gpx) and Glutathione-STransference (GST) in the brain tissue of differently treated mice. Group I: Control, Group II: Alloxan treated, Group III: Alloxan + Metformin treated mice. 


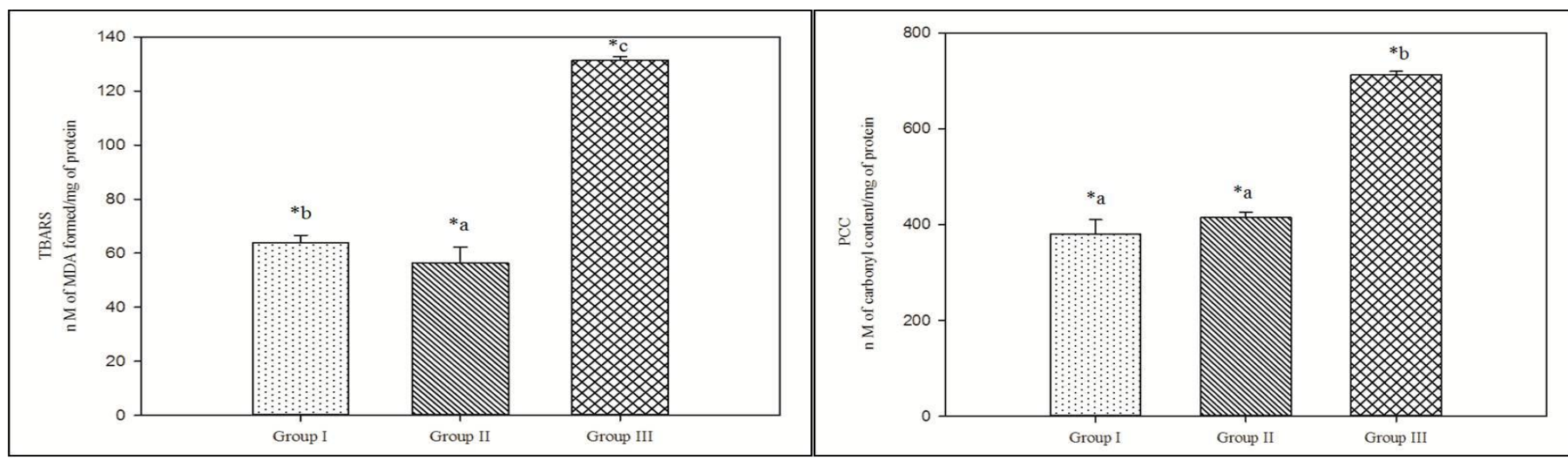

Fig. 5: Thio Barbutyric Acid Reactive Substances (TBARS) and Protein Carbonyl Content (PCC) levels in the brains of differently treated mice. Group I: Control, Group II: Alloxan treated, Group III: Alloxan + Metformin treated mice.

The present investigation revealed the levels of oxidative stress indicated by the markers as TBARS and PCC. TBARS level was measured maximum in group III (131.4 $\pm 1.368 \mathrm{nM}$ of MDA formed per mg of protein) followed by group I $(63.87 \pm 2.801 \mathrm{n}$ M of MDA formed per $\mathrm{mg}$ of protein) and group II (56.34 $\pm 6.006 \mathrm{nM}$ of MDA formed $/ \mathrm{mg}$ of protein) $(p<0.05)$. In PCC oxidative stress was measured highest in group III (712.888 $\pm 7.298 \mathrm{nM}$ of carbonyl content per $\mathrm{mg}$ of protein) and minimum in group I (379.7 $\pm 30.8 \mathrm{nM}$ of carbonyl content/mg of protein); in group II (415.2 \pm $11.25 \mathrm{nM}$ of carbonyl content/mg of protein) $(p<0.05)$ (Fig. 5).

\section{DISCUSSION}

Various studies show that alloxan exerts diabetogenic action upon administration intravenously, intraperitoneally, or subcutaneously to animals. [39] Activity of antioxidant enzyme in diabetic mice is enhanced except GST. Endogenous antioxidants (SOD, $\mathrm{GSH}, \mathrm{CAT}$ and GpX) levels were found incremented in diabetic mice, with respect to control whereas in Metformin treated diabetic group, levels of endogenous antioxidants were noted positively correlating with the elevated total protein content in the brain tissue. ${ }^{[47]}$ In our study level of endogenous antioxidant enzyme except GST gradually increase in diabetic mice and it declines when treated with Metformin. Resulted in elevation of proteins and endogenous antioxidant in diabetic mice were recorded under in vivo conditions. Whereas activity of GST in diabetic mice was increased and it declined when diabetic mice were treated with Metformin. Decline in the activities of antioxidants generates free radicals due to which tissue injury appears. [46] Therefore, Metformin shows protective behavior only in GST. Endogenous antioxidant, enzymes (SOD and GSH) declines in Metformin treated diabetic mice due to inactivation of enzyme protein by ROS that depletes the substrate for enzyme and down regulates the transcription and translation process. [42] The study exhibits that diabetes induced oxidative stress is at parallel with control but when diabetic mice treated with Metformin then oxidative stress generates due to some adverse action of Metformin. Therefore there is still a quest for alternative medicine for diabetes. Many people rely on herbal medication for diabetes. This leads to the immense need to find a potent antihyperglycemic control system that can eliminate endogenous antioxidants thereby controlling oxidative stress.

\section{ACKNOWLEDGEMENTS}

Authors express gratitude to Professor Aditya Shastri, Vice-Chancellor, Banasthali Vidyapith, Rajasthan. We also provide thanks to DST-CURIE for providing financial assistance for conducting our research work.

\section{REFERENCES}

1. Jarald E, Joshi SB, Jain DC. Diabetes and herbal medicines. IJPT. 2008; 7(1): 97-106.

2. Patcharanarumol W, Panichkriangkrai W, Wango S. Diabetes prevention and care in the universal health coverage context: the example of thailand. WHO South--East Asia J Public Health. 2016; 5(1): 27-33.

3. Simmons KM, Michels AW. Type 1 diabetes: A predictable disease. World J Dia. 2015; 6(3): 380-390.

4. Lindley S, Dayan CM, Bishop A, Roep BO, Peakman M, Tree TIM. Defective suppressor function in CD4+ CD25+ t-cells from patients with type 1 diabetes. Dia. 2005; 54(1): 92-9.

5. Fu Z, Gilbert ER, Liu D. Regulation of insulin synthesis and secretion and pancreatic beta-cell dysfunction in diabetes. Curr Dia Rev. 2013; 9: 25-53.

6. Rodger W. Non-insulin-dependent (type II) diabetes mellitus. Canadian Med Ass. 1991; 145(12): 1571-1581.

7. Butler AE, Janson J, Weir SB, Ritzel R, Rizza RA, Butler PC. $\beta$ cell Deficit and increased $\beta$-cell apoptosis in humans with type 2 diabetes. Dia. 2012; 52(1): 102-10.

8. American Diabetes Association. Diabetes Care. The J Clin and App Res and Edu. 2017; 40: S1-S2.

9. Vestergaard P. Discrepancies in bone mineral density and fracture risk in patients with type 1 and type 2 diabetes-a meta-analysis. Osteoporos Int. 2007; 18(4): 427- 444.

10. Khan IA, Mowa S, Shaik NA, Chava S, Jahan P, Mukkaval KK, Kamineni V, Hasan Q, Rao P. Investigation of Calpain 10 (rs2975760) gene polymorphism in asian Indians with gestational diabetes mellitus. Meta Gene. 2014; 2: 299-306.

11. Cade WT. Diabetes-related microvascular and macrovascular diseases in the physical therapy setting. Phy Ther. 2008; 88(11): 1322-35.

12. Soto CP, Perez BL, Favari LP, Reyes JL. Prevention of alloxaninduced diabetes mellitus in the rat by silymarin. Comparative Biochemistry and Physiology Part C: Comparative Pharmaco. 1998; 119(2): 125-9.

13. Ravikumar P, Anuradha CV. Effect of fenugreek seeds on blood lipid peroxidation and antioxidants in diabetic rats. Phytotherapy Res. 1999; 13: 197-201. 
14. Jafri MA, Aslam M, Jave K, Singh S. Effect of Punica granatum Linn. (flowers) on blood glucose level in normal and alloxaninduced diabetic rats. J of Ethnopharmacol. 2000; 70 (3): 30914.

15. Szkudelski T. The mechanism of alloxan and streptozotocin action in b cells of the rat pancreas. Physiol Res. 2001; 50: 536 46.

16. Dhandapani S, Subramanian VR, Rajagopal SK, Namasivayam N. Hypolipedemic effect of Cuminum cyminum on alloxan- induced diabetic rats. Pharmacol Res. 2002; 46(3): 251-55.

17. Sharma SB, Nasir A, Prabhu KM, Murthy PS, Dev G. Hypoglycaemic and hypolipidemic effect of ethanolic extract of seeds of Eugenia jambolana in alloxan-induced diabetic rabbits. J of Ethnopharmacol. 2003, 85(2-3): 201-6.

18. Prince PS, Kamalkkanna N, Menon VP. Antidiabetic and antihyperlipidaemic effect of alcoholic Syzigium cumini seeds in alloxan induced diabetic albino rats. J of Ethnopharmacol. 2004; 91(2-3): 209-13.

19. Alfy AT, Ahmad AAE, Fatani AJ. Protective effect of red grape seeds proanthocyanidins against induction of diabetes by alloxan in rats. Pharmacol Res. 2005; 52(3): 264-70.

20. Odetola AA, Akinloye O, Egunjobi C, Adekunle WA, Ayoola AO. Possible antidiabetic and antihyperlipidaemic effect of fermented Parkia biglobosa (JACQ) extract in alloxan-induced diabetic rats. Clin Exp Pharmaco Physiol. 2006; 33(9): 808-12.

21. Lenzen S. The mechanism of alloxan and streptozotocin induced diabetes. Diabetol. 2008, 51(2), 216-26.

22. Bakirel T, Bakirel U, Keles OU, Ulgen SG, Yardibi H. In vivo assessment of antidiabetic and antioxidant activities of rosemary (Rosmarinus officinalis) in alloxan-diabetic rabbits. J of Ethnopharmacol. 2008; 116(1): 64-73.

23. Shu XS, Hail J, Tao J, Li GM, Li HD, Ma N Antihyperglycemic effects of total flavonoids from Polygonatum odoratum in STZ and alloxan-induced diabetic rats. J of Ethnopharmacol. 2009; 124(3): 539-43.

24. Jain S, Bhatia G, Barik R, Kumar P, Jain A, Dixit VK. Antidiabetic activity of Paspalum scrobiculatum Linn. in alloxan induced diabetic rats. J of Ethnopharmacol . 2010; 127(2): 325-8.

25. Dahech I, Belghith KS, Hamden K, Feki A, Belghith $\mathrm{H}$, Mejdoub H. Antidiabetic activity of leven polysaccharide in alloxan-induced diabetic rats. Int J of Biol Macromol. 2011; 49(4): 742-46.

26. Rohilla A, Ali S. Alloxan induced diabetes: mechanisms and effects. Int J of Res in Pharm Biomed Sci. 2012; 3(2): 819-23.

27. Mamum AI, Islam S, Alam AHMK, Rahman, MAA, Rashid M. Effects of ethanolic extract of Hibiscus rosa-sinensis leaves on alloxan-induced diabetes with dyslipidemia in rats. Bangladesh Pharm J. 2013; 16(1): 27-31.

28. Alam MM, Meerza D, Naseem I. Protective effect of quercetin on hyperglycemic, oxidative stress and DNA damage in alloxan induced type 2 diabetic mice. Life Sci. 2014; 109(1): 814.

29. Kumar K, Pant NC, Ahmad S, Fateh MV, Rai AK, Verma B, Chaurasia H. Development and evaluation of floating microsheres of curcumin in alloxan-induced diabetic rats. Trop J Pharm Res. 2015; 15(9): 1819-25.

30. Radenkovic M, Stojanovic M, Prostran M. Experimental diabetes induced by alloxan and strepzotocin: the current state of the art. J Pharm Toxicol Meth. 2016; 78: 13-31.

31. Mithieux G, Guignot L, Bordet J, Wiernsperger N. Intrahepatic mechanisms underlying the effect of metformin in decreasing basal glucose production in rats fed a high-fat diet. Dia. 2002; 51(1): 139-43.
32. Formoso G, Filippis EADe, Michetti N, Fulvivo PD, Pandolfi A, Bucciarelli T, Ciabattoni G, Nicolucci A, Davi G, Consoli A. Decreased in vivo oxidative stress and decreased platelet activation following metformin treatment in newly diagnosed type 2 diabetic subjects. Dia. Metab Res Rev. 2008; 24: 231-37.

33. Patade GR, Marita AR. Metformin: A journey from countryside to the bedside. J Obes Metabol Res. 2014; 1(2): 127-130

34. Cade WT. Diabetes-related microvascular and macrovascular diseases in the physical therapy setting. Phys Ther. 2008; 88(11): 1322-35.

35. Miyata T, Kurokawa K, De Striho CVY. Relevance of oxidative and carbonyl stress to long-term uremic complications. Kidney Int. 2000; 58(76): 120-5.

36. Franco R, Panayiotidis MI. Environmental toxicity, oxidative stress, human disease and the black box of their synergism: how much have we revealed. Mutat Res. 2009; 674: 1-2

37. Maritim AC, Sanders RA, Watkins III JB. Diabetes, Oxidative Stress and Antioxidants: A Review. J Biochem Mol Toxicol. 2003; 17(1): 1-38.

38. Togashi Y, Shirakawa J, Okuyama T, Yamazaki S, Kyohara M, Miyazawa A, Suzuki T, Hamada M, Terauchi Y. Evaluation of the appropriateness of using glucometers for measuring the blood glucose levels in mice. Sci Rep. 2016; 6: 1-9.

39. Njogu SM, Arika WM, Nyamai DW, Ngugi MP, Machocho AK, Ngeranwa JJN, Njag ENM. Hypoglycemic effects of aqueous and ethyl acetate leaf extract of Maytenus putterkloides in alloxan induced diabetic mice. J Dia Metabol. 2016; 7(6): 1-7.

40. Raafat K, Lakany AE. Acute and sub chronic in-vivo effects of Ferula hermonis L. and Sambucus nigra L. and their potential active isolates in a diabetic mouse of neuropathic pain. Complement Altern Med. 2015; 15(257): 1-14.

41. Lowry OH, Rosebrough NJ, Farr AL. Protein measurement with the folin phenol reagent. J Biol Chem. 1951; 265-75.

42. Ellman GL. Tissue sulfhydryl groups. Arch Biochem Biophy. 1959; 82: 70-7.

43. Dhindsa RH, Plumb-Dhindsa P, Thorpe TA. Leaf senescence correlated with increased level of membrane permeability, lipid peroxidation and decreased level of SOD and CAT. Int Exp Bot. 1981; 32: 93-101.

44. Claiborne A. Catalase activity. In: Greenwald, R.A., Ed., CRC Handbook of Methods for Oxygen Radical Research, CRC Press Boca Raton. 1985; 283-84.

45. Mohandas J, Marshal J, Duggin G, Horvath JS, Tiller D. Differential distribution of glutathione and glutathione related enzymes in rabbit kidney. Canc Res. 1984; 44: 5086-91.

46. Habig WH, Pabst MJ, Jacoby WB. Glutathione S-transferases: the first enzymatic step in mercapturic acid formation. J Biol Chem. 1974; 249: 7130-39

47. Ohkawa, H, Ohishi N, Yagi K. Assay for lipid peroxides in animal tissues by thiobarbituric acid reaction. Anal Biochem. 1979; 95: 351-8.

48. Levine RL, Garland D, Oliver CN, Amici A, Climent I, Lenz AG, Ahn BW, Shaltiel S, Stadtman ER. Determination of carbonyl content in oxidatively modified proteins. Meth Enzymol. 1990; 186: 464-478.

49. Misra M, Aiman U. Alloxan: An unpredictable drug for diabetes induction. Indian J Pharmacol. 2012; 44: 538-539.

50. Bukhari SSI, Abbasi MH, Khan MKA. Dose optimization of alloxan for diabetes in albino mice. Biologia. 2015; 61(2): $301-$ 305. 